\title{
Combating the constitutional crisis in Poland - Can the European Union provide an effective remedy?
}

\author{
MONIKA KAWCZYŃSKA*
}

Chair of European Law, Department of Law and Administration, Jagiellonian University, Poland

\section{ORIGINAL RESEARCH PAPER}

Received: February 5, 2020 • Revised manuscript received: May 8, 2020 • Accepted: May 25, 2020

Published online: August 14, 2021

(c) 2020 Akadémiai Kiadó, Budapest

\section{ABSTRACT}

Recent constitutional reforms in Poland have demonstrated a lack of respect for the rule of law and for the fundamental values which form the foundations of the EU legal order. The Polish authorities have substantially deviated from principles that the country has accepted as a part of the Copenhagen criteria. The aim of the article is to analyse the mechanisms and procedures applied by the EU institutions to address the systemic threats to the rule of law in Poland. The main focus of the assessment is on the effectiveness of the measure and its potential for a proper solution to the problem. The response provided by the EU demonstrate that there has been a shift from a political to judicial enforcement of values. The article argues that the remedies that were deemed to be the least suitable to address the systemic deficiencies in the rule of law - an infringement action and a preliminary ruling procedure - proved to be the most effective remedy to defend independence of the Polish judiciary. Unexpectedly, the most efficient institution to ensure the respect for values enshrined in Article 2 TEU in Poland proved to be the CJEU, providing extensive interpretation of Article 19 (1) TEU and Article 47 of the Charter. Nevertheless the values are still much more difficult to enforce than the law. While the most serious infringements have been reversed, this has not prevented the Polish authorities from further violating the rule of law.

\section{KEYWORDS}

rule of law, Poland, constitutional crisis, independence of the judiciary, Article 7 TEU, infringement action, preliminary rulings

\footnotetext{
*Corresponding author. E-mail: monika.kawczynska@uj.edu.pl
} 


\section{INTRODUCTION}

Poland, after liberation from Soviet domination in 1989, was one of the most successful posttransitional democracies in Central Europe and a solid example of a democratic state governed by law. In 1997 the Parliament adopted liberal-democratic constitution based on the rule of law, the separation of powers with due checks and balances, political pluralism and a broad catalogue of fundamental rights effectively safeguarded by independent courts and tribunals. ${ }^{1}$ However in recent times the country of established constitutional democracy appear to be turning back toward an authoritarian state architecture. ${ }^{2}$

Controversial reforms that have recently occurred in Poland have been described as democratic backsliding or even more accurately as 'anti-constitutional populist backsliding. ${ }^{3}$ The Law and Justice (Prawo i Sprawiedliwość), national conservative political party that won parliamentary elections in October 2015, adopted series of statutes that amended the Constitution without required procedure. Poland's Constitution is considered to be a 'rigid constitution' because the process of amendment prescribed in its Article 235 is detailed and requires broad political consensus due to high threshold. The governing party does not enjoy a constitutional majority in the Parliament in order to change the existing, according to its leader's words, 'postCommunist Constitution'.

The constitutional crisis began in November 2015 with the aim of taking control of the Constitutional Tribunal (Trybunat Konstytucyjny). The newly elected Parliament cancelled the appointment of five previously elected judges and through accelerated legislative procedure adopted series of bills intended to paralyse the functioning of the Tribunal. Moreover, the President refused to swear in three legally elected judges and the Prime Minister declined to publish over 20 Tribunal's judgements. Since the end of 2016, after an effective 'court-packing', the Constitutional Tribunal has been actively used to obtain judgements favourable to the ruling majority. ${ }^{4}$

In 2017 the Government announced a comprehensive reform of the judiciary comprising a set of laws concerning reorganization of the ordinary courts. Within six months, the Minister of Justice (who is also the Prosecutor General) dismissed over 150 presidents and vice presidents of the ordinary courts. Subsequently the governing majority took over the National Council for the Judiciary (Krajowa Rada Sadownictwa), prematurely terminating the mandates of its members elected by the gatherings of the judges. The final act involved changes to the organization and functioning of the Supreme Court (Sad Najwyzszy), including lowering the retirement age of judges from 70 to 65 years of age. It interfered with the tenure of a significant number of current Supreme Court judges as well as the President of the Supreme Court whose six-year term of

\footnotetext{
${ }^{1}$ Biernat and Kawczyńska (2019) 748-49.

${ }^{2}$ Tóth (2017) 9.

${ }^{3}$ Sadurski (2018) 9-10.

${ }^{4}$ See for example: judgement of 17 July 2018, ref. no K 9/17 and judgement of 26 June 2019, ref. no K 8/17 (application an act of pardon by the President); judgement of 24 October 2017, ref. no K 3/17 (election procedure of the First President of the Supreme Court); judgement of 20 June 2017, ref no. K 5/17 (election procedure of the National Council of the Judiciary); judgement of 11 September 2017, ref. no K 10/17 (election procedure of a judge, the President and the VicePresident of the Constitutional Tribunal); judgement of 26 June 2019, ref. no K 16/17 (invoking the conscience clause while providing services), judgement of 20 April 2020, ref. no U 2/20 (the resolution of the Supreme Court concerning the judges appointed by the new National Council of the Judiciary).
} 
office is constitutionally guaranteed. ${ }^{5}$ Subsequent illiberal reforms concern the introduction of the 'Muzzle Law' intended to discipline judges for criticising judicial reform and submitting the preliminary questions to the Court of Justice (CJEU). The Polish authorities openly challenge the authority of the judgements issued in the preliminary ruling procedure and their enforcement by the Supreme Court.

Several international institutions have actively reacted to legislative reforms in Poland, including the European Commission for Democracy through Law (the Venice Commission), ${ }^{6}$ the UN Human Rights Committee, ${ }^{7}$ Commissioner for Human Rights of the Council of Europe ${ }^{8}$ and Amnesty International. ${ }^{9}$ Nevertheless the most significant response came from the European Union, the organisation obliged to ensure that its Member States comply with the values enshrined in Article 2 of the Treaty on the European Union (TEU).

The aim of the article is to analyse the procedures applied by EU institutions to address systemic threats to the rule of law in Poland. The EU has proposed various mechanisms to address the constitutional crisis, with all related strengths and weaknesses. The main focus of the assessment is on the effectiveness of the measure and its potential for a proper solution to the problem. The article examines a number of remedies provided for in the Treaties, as well as measures adopted by the Commission within the Rule of Law Framework.

\section{POLITICAL V. JUDICIAL ENFORCEMENT OF VALUES}

The EU legal structure is based on the premise that all Member States recognise and share a set of common values on which the EU is founded. This justifies the existence of mutual trust between Member States respecting the fundamental values of the EU and thus observing the laws that implements these values. ${ }^{10}$ Respect for values enshrined in Article 2 TEU such as human dignity, freedom, democracy, equality, the rule of law and human rights are indispensable preconditions for accession to the EU. Recognition of the basic values leads the EU out of the group of international organisations having an economic character and strengthens the constitutional nature of the Union's identity. ${ }^{11}$ The promotion and protection of the Union's values is an objective and a duty of the European Union, which is implemented through its institutional framework (Article 3(1) and 13(1) TEU). Ensuring respect for the values is not exclusively a judicial task but is mainstreamed into the activities of all EU institutions. ${ }^{12}$ While

${ }^{5}$ For a comprehensive analysis of the legal changes that have taken place in Poland see Sadurski (2019).

${ }^{6}$ Since 2016 the Venice Commission has issued several opinions concerning amendments to the Act on the Constitutional Tribunal, the Act on the Public Prosecutor's office, the Act on the National Council of the Judiciary, the Act on the Supreme Court and on the Act on the Organisation of Ordinary Courts: <https://www.venice.coe.int/webforms/ documents/?country $=23 \& y e a r=$ all $>$ accessed 1 May 2020.

${ }^{7}$ UN Human Rights Committee, 'Concluding observations on the seventh periodic report of Poland', (2016)<https:// www.ecoi.net/en/file/local/1019364/1930_1481718762_g1626078.pdf > accessed 1 May 2020.

${ }^{8}$ Mijatović (Commissioner for Human Rights of the Council of Europe) (2019).

${ }^{9}$ Amnesty International (2019).

${ }^{10}$ Opinion 2/13, ECLI:EU:C:2014:2454, 168.

${ }^{11}$ Mangiameli (2013) 114.

${ }^{12}$ Hillion (2016) 62. 
performing its duties the European Union must consider its autonomous structure and the limits specified in the acquis. The EU competences are governed by the principle of conferral, and their exercise is governed by the principles of subsidiarity, proportionality and respect for national identities of the Member States. On the other hand, the principles of primacy and sincere cooperation preclude Member States from invoking their national law, even of a constitutional nature, to justify a breach of fundamental values. There is a trend to rely on sovereignty or the principle national identity (Article 4 (2) TEU) to justify non-compliance with EU law, followed by disrespect to fundamental values. ${ }^{13}$ Respect for the rule of law is inherent to the legal systems of modern and democratic states and should form a part of the national identity as well.

The rule of law is regarded as a constitutional principle of the European Union. The CJEU in Les Verts stated that it is 'a Community based on the rule of law, inasmuch as neither its Member States nor its institutions can avoid a review of the question whether the measures adopted by them are in conformity with the basic constitutional charter, the Treaty. ${ }^{14}$ Thus the rule of law in the Union legal order is not only a formal and procedural requirement, but also has a substantive value. ${ }^{15}$ Considering the acquis of the Council of Europe and the constitutional traditions of the EU Member States, core elements can be identified stemming from the rule of law such as legality, legal certainty, prohibition of arbitrariness of the executive powers, independent and impartial courts, effective judicial review including respect for fundamental rights and equality before the law. ${ }^{16}$ Thus the rule of law concept is intrinsically linked to democracy and fundamental rights, ensuring compliance and respect for all fundamental values listed in Article 2 TEU.

Where national measures are not capable of addressing the threats to the rule of law in a Member State, the EU institutions have a responsibility to remedy the existing deficiencies. The European Union has at its disposal different set of procedures to enforce the values enshrined in Article 2 TEU and to ensure the compliance with EU law.

The most important mechanism to enforce fundamental values is provided for in Article 7 TEU. Is has its origins in the Treaty of Amsterdam and it was adopted with the prospect of Eastern enlargement. ${ }^{17}$ The procedure provided for in Article 7 TEU is considered as a political instrument, due to the limited involvement of the Commission and restricted jurisdiction of the judicature (Article 269 TFEU). The Treaty gives only limited authority to the CJEU to determine whether the institutions have acted lawfully to ensure the respect by the Member States of the principles laid down under Article 2 TEU or to adjudicate on the lawfulness of acts adopted on the basis of Article $7 \mathrm{EU}{ }^{18}$ On the other hand, there are legal instruments where the judicial

\footnotetext{
${ }^{13}$ Chancellery of the Prime Minister, White Paper on the Reform of the Polish Judiciary, 7 March 2018, <https://www. premier.gov.pl/files/files/white_paper_en_full.pdf> accessed 1 May 2020.

${ }^{14}$ Case 294/83 Parti écologiste 'Les Verts' v European Parliament, EU:C:1986:166, para 23.

${ }^{15}$ Pech (2009) 53.

${ }^{16}$ European Commission, Communication to the European Parliament and the Council. A new EU Framework to strengthen the Rule of Law, $\operatorname{COM(2014)~} 158$ final, 4; European Commission for Democracy through Law (Venice Commission), Report on the rule of law, adopted by the Venice Commission at its 86th plenary session (Venice, 25-26 March 2011), 10.

${ }^{17}$ Sadurski (2010) 382.

${ }^{18}$ Case T-337/03, Luis Bertelli Gálvez v Commission, ECLI:EU:T:2004:106.
} 
authority plays a major role. In case of singular infringements of EU law the Commission is empowered to initiate the ordinary enforcement proceedings envisaged in Articles 258 and 260 TFEU and request interim measures to suspend national provisions violating EU law. The CJEU ensures the uniform application of EU law and the respect for fundamental values in the national legal orders through preliminary ruling procedure.

The difference between these procedures lies in their scope of application. Article 7 TEU is designed to address serious and persistent threats to the values enshrined in Article 2 TEU, whereas the latter proceedings cover individual violations of the EU law by the Member States. Moreover, mechanism specified in Article 7 TEU is not limited to areas where Member Stares applying or implementing EU, but also covers actions where the Member States act autonomously. A broad interpretation of the scope of Article 7 TEU is necessary to ensure that it can serve as an effective measure for protecting EU values. ${ }^{19}$ In contrast, infringement proceedings or preliminary rulings are designed to ensure compliance with the fundamental values only when the Member States act within the scope of Union law. ${ }^{20}$ In principle, the latter proceedings are not intended to tackle systemic deficiencies in the rule of law. The Polish example demonstrates that the EU institutions decided to deploy a patchwork of measures to prevent violations of fundamental principles in the context of the constitutional crisis. It was determined by the nature of the Polish government's actions, which were far-reaching and destructive to democratic institutions.

\section{APPLYING ARTICLE 7 TEU - THE EUROPEAN UNION'S ‘NUCLEAR OPTION'}

Article 7(1) TEU provides for a preventive mechanism that can be activated in case of a 'clear risk of a serious breach' of the values referred to in Article 2 TEU while Article 7(2) TEU establishes a sanctioning mechanism only in case of a 'serious and persistent breach by a Member State' of these values. It should only be triggered in exceptional circumstances when the Member States significantly deviate from the values forming the foundations of the Union. Legal scholars suggest that Article 7 TEU shall be used in cases of a 'systemic deficiency in the rule of law', that exists if this founding principle is substantially threatened and shall be distinguished from simple, episodic infringements of the law. ${ }^{21}$ Therefore it is regarded as an ultimate remedy and is often referred to as the 'nuclear option'. 22 This metaphor is severely criticised in legal doctrine as an overstatement that could result in misplaced complacency and preventing the EU from deploying the mechanism compared to solution of atomic nature. ${ }^{23}$

In March 2014, the European Commission adopted the Rule of Law Framework as a complementary instrument for addressing systemic threats to the rule of law. It established an

\footnotetext{
${ }^{19}$ Kochenov (2019) 92.

${ }^{20}$ European Commission, Communication From The Commission to the Council and the European Parliament on Article 7 of the Treaty on European Union. Respect for and promotion of the values on which the Union is based. $\operatorname{COM}(2003) 606$ final.

${ }^{21}$ Von Bogdandy and Ioannidis (2014) 71-73.

${ }^{22}$ Barroso (2013).

${ }^{23}$ Besselink (2017) 134.
} 
early warning tool allowing the Commission to enter into a dialogue with the Member State to prevent the escalation of systemic threats to the rule of law to the point where the procedure set out in Article 7 TEU need to be initiated. In view of the Commission, the mechanism shall be used in situations where 'the authorities of a Member State are taking measures or are tolerating situations which are likely to systematically and adversely affect the integrity, stability or the proper functioning of the institutions and the safeguard mechanisms established at national level to secure the rule of law. ${ }^{24}$ In contrast, the Council Legal Service considered the new supervision mechanism to be in violation of the principle of conferral since the Commission had no competence to amend, modify or supplement the procedure laid down in Article 7 TEU. ${ }^{25}$ The case of constitutional disruption in Poland was the first, and so far, the only time when the Rule of Law Framework has been activated. The Commission have decided to initiate the framework only once, even when it was explicitly invited to do so by the European Parliament in the case of Hungary. $^{26}$

The Commission's preliminary assessment for Poland started in January 2016, just after legal 'attack' on the functioning of the Constitutional Tribunal. During the first phase of the dialogue, the parties exchanged series of letters and held meetings at various levels to seek a satisfactory resolution of the 'constitutional deadlock'. The Polish Government did not take any substantial action necessary to address these problems in a satisfactory manner to resolve the issue so in June 2016 r. the Commission adopted the Rule of Law Opinion on the situation in Poland. ${ }^{27}$ The Commission identified three main issues which seriously undermined the rule of law: lack of publication and non-compliance with the Constitutional Tribunal's rulings concerning the appointment of judges, series of legislative changes impeding the organization of the Constitutional Tribunal and deficiency in the constitutional review of new legislation which have been adopted and enacted by the parliamentary majority. Failure of the Polish authorities to take corrective measures led the Commission to the second stage of the framework and adoption of two recommendations in 2016 concerning situation in Constitutional Tribunal. ${ }^{28}$ In view of the Commission, the absence of effective constitutional justice system posed a systemic threat to the rule of law in Poland. Two further recommendations issued by the Commission in 2017 related to the adoption by the Polish Parliament of new legislation on the Supreme Court, the National Council for the Judiciary and on the Ordinary Courts Organisation, raising grave concerns as regards judicial independence. ${ }^{29}$

\footnotetext{
${ }^{24}$ European Commission, Communication to the European Parliament and the Council. A new EU Framework to strengthen the Rule of Law, $\operatorname{COM}(2014) 158$ final, 6.

${ }^{25}$ Council of the European Union, Opinion of the Legal Service Commission's Communication on a new EU Framework to strengthen the Rule of Law, Brussels 27 May 2014.

${ }^{26}$ Sargentini and Dimitrovs (2016) 1086.

${ }^{27}$ Pech (2016).

${ }^{28}$ European Commission, Recommendation 2016/1374 of 27 July 2016 regarding the rule of law in Poland, OJ [2016] L 217/53; European Commission, Recommendation (EU) 2017/146 of 21 December 2016 regarding the rule of law in Poland complementary to Recommendation (EU) 2016/1374, OJ [2017] L22/65.

${ }^{29}$ European Commission, Recommendation (EU) 2017/1520 Of 26 July 2017 regarding the rule of law in Poland complementary to recommendations (EU) 2016/1374 and (EU) 2017/146, OJ [2018] L228/19; European Commission, Recommendation (EU) 2018/103 of 20 December 2017 regarding the rule of law in Poland complementary to recommendations (EU) 2016/1374, (EU) 2017/146 and (EU) 2017/1520, OJ [2018] L17/50.
} 
The dialogue conducted with Polish authorities within a period of two years proved to be ineffective. At that time, the governing majority adopted a number of consecutive laws which seriously affected the entire structure of the Polish judicial system. The launch of the Rule of Law Framework merely 'helped identifying problems and framing the discussion'. Adoption by the Commission of rule of law opinion and four recommendations did not prevent a further deterioration of the constitutional crisis. Therefore in December 2017 the Commission decided to take further step formally involving the European Parliament and the Council. The Commission submitted a reasoned proposal in accordance with Article 7(1) TUE regarding the rule of law in Poland. ${ }^{30}$ In 2018, during the first stage of the procedure on the determination of a clear risk of a serious breach of the rule of law, the Council held three hearings. After long and fruitless discussion concerning situation in Poland, ministers still have not taken a formal decision. The lack of progress and inefficiency in the Council's actions was acknowledged by the Commission stating that the actions undertaken by the Council 'could have been more meaningful' and application of the Article 7 in practice 'still need to prove to be fully effective. ${ }^{31}$ The European Parliament also pointed out that the hearings organised by the Council under preventive mechanism 'are not organised in a regular, structured and open manner'. It called on the Council to address concrete recommendations to the countries concerned, including deadlines, to ensure EU law is respected. ${ }^{32}$

In case of Poland, the supervision mechanism has proved to be ineffective and have not prevent the illiberal reforms or rather so called 'constitutional vandalism'. For over four years the European institutions have not taken any effective and formal decision, that could actually discourage the governing majority from further infringements of the rule of law. The mechanisms designed to protect the fundamental values revealed its complicated nature. Adding the stages foreseen in the mechanism under Article 7 TEU to the sum of the possible phrases in the framework procedure, gives at least thirteen steps before taking the final decision on the suspension of certain rights of the Member State. ${ }^{33}$

The debate within the Rule of Law Framework initiated by the Commission in January 2016 was conducted for almost two years. It was a prompt response with an unsuccessful ending. The Polish authorities engaged in a dialogue, but it appears that the only objective was to postpone the activation of the mechanism under Article 7 TEU. The ruling majority was exploring how far they were allowed to move with the unconstitutional changes. The soft law instruments issued by the Commission - the opinion and the four recommendations - have not affected the Polish authorities in any way. The same applies to the five recommendations issued by the Venice Commission, which to date remain unimplemented in Poland. The Rule of Law Framework has lacked the necessary legitimacy reflected in a uniform approach of all EU institutions towards the legality of the supervision mechanism. The opinion of the Council Legal Service concerning the illegality of the framework was scrupulously exploited by the Polish authorities. Instead of

\footnotetext{
${ }^{30}$ European Commission, Proposal for a Council decision on the determination of a clear risk of a serious breach by the Republic of Poland of the rule of law $(\operatorname{COM}(2017) 835$.

${ }^{31}$ European Commission, Communication of the European Parliament, the European Council and the Council Further strengthening the Rule of Law within the Union. State of play and possible next steps, COM(2019)163 final.

${ }^{32}$ European Parliament resolution of 16 January 2020 on ongoing hearings under Article 7(1) of the TEU regarding Poland and Hungary (2020/2513(RSP)).

${ }^{33}$ Österdahl (2019) 256.
} 
conducting constructive dialogue and searching for effective solutions, the governing majority questioned the legality of the mechanism and threatened the Commission with action for annulment. The case of Poland shows that the observers were right about the shortcomings of the Rule of Law Framework, based on the highly questionable assumption that discursive approach must produce positive results. ${ }^{34}$

It can be also argued, that former historical implications prevented the EU from effectively applying in Poland the mechanism provided for in Article 7 TEU. It was first considered in response to the participation of the extreme-right Freedom Party (FPÖ) in the Austrian government, which, after thorough investigation did not reveal a breach of fundamental values. ${ }^{35}$ There are other allegations against Article 7 TEU concern its vagueness and the high level of abstraction of the fundamental values in Article 2 TEU. It all might give the impression of a 'tool which is rather blunt'. ${ }^{36}$ The procedure enshrined in Article 7 TEU is considered as being largely political and requiring a high decision-making threshold to bring the Member States into compliance. ${ }^{37}$ Such a mechanism is very difficult to apply because it imposes a very high voting requirement - four fifths in the Council and the unanimity in the European Council. Presumably the Polish government is not concerned about the activation of the sanctioning mechanism as Hungary announced a veto to defend Poland.

Nevertheless in the present state of affairs the main problem lies with the inaction of the Council. Article 7(1) TUE provides for preventive mechanism where no sanctions can be imposed on the Member State concerned and in fact is a warning before a 'serious breach' has actually materialized. For more than two years, only three hearings were held, which were not organised in an structured and open manner and were not followed by any recommendations. The Council did not order a voting to determine whether there was a clear risk of a serious breach of the values referred to in Article 2 TEU. The institution remains in a state that can be described as a 'wishful reluctance'. The underlying motive may be twofold. Either the Council is concerned that it will not reach the required voting threshold or it believes that the 'naming and shaming' procedure is sufficient to discourage Polish authorities from engaging in the further violations. It seems to be a major drawback since the governing majority in Poland attempts to follow the Hungarian and Turkish pattern and does not intend to refrain from undemocratic reforms. As a result, the political mechanisms designed to safeguard the fundamental values in the European Union legal order have significantly failed to protect the constitutional values in Poland.

\section{INFRINGEMENT PROCEEDINGS - A SURPRISINGLY EFFECTIVE SOLUTION?}

Prior to the constitutional crisis in Poland, there was an debate whether infringement proceedings may be used to address systemic deficiencies in the rule of law. In other words, whether the respect for the values enshrined in Article 2 TEU may be the subject of judicial enforcement

\footnotetext{
${ }^{34}$ Kochenov and Pech (2016) 1066.

${ }^{35}$ Sadurski (2010) 382.

${ }^{36}$ Wilms (2017) 5; Hillion (2016) 67.

${ }^{37}$ Besselink (2017) 143.
} 
or only political mechanism under Article 7 TEU. Article 258 TFEU stipulates that the Commission may act when a Member State has failed to fulfil an obligation 'under the Treaties'. There is only one express limitation provided for in Article 24 (1) TEU with respect to the Common Foreign and Security Policy. There was a view that the wording of Article 2 TEU is not sufficiently precise to give rise to legal obligations that are amenable to judicial control and such a provision cannot by itself constitute a basis for an infringement action. ${ }^{38}$ It follows that the Commission may institute the proceedings when the Member State violates fundamental values in relation to the breach of certain provisions of primary or secondary law. In that regard an infringement action may address violations of the values only when the Member State acts within the scope of EU law. The procedure under Article 7 TEU cannot be treated as lex specialis for monitoring and sanctioning non-compliance with EU values, having priority or excluding the application of the mechanism described in Article 258 TFEU. $^{39}$ The mechanism provided for in Article 7 TEU is considered to be complementary ${ }^{40}$ or even subsidiary ${ }^{41}$ to infringement action.

Considering the possibility of applying the infringement procedure against Member States deviating from the principles of Article 2 TEU, there are other shortcomings that should be considered. The procedure enshrined in Article 258 TFEU is regarded as inadequate to address infringements of the values described in Article $2 \mathrm{TEU}$, as 'too case-specific ${ }^{42}$ and targeted at individual infringements. ${ }^{43}$ Some commentators proposed to use so called 'systemic infringement actions' where Commission could bundle a group of specific alleged violations together and argue that the infringement of EU law in a Member State is systemic and persistent. ${ }^{44}$ However, to date, the Commission has not decided to follow this view and continues to initiate proceedings to tackle the singular infringements of law.

Moreover, the action described in Article 258 TFEU is largely dependent on the Commission's discretion to initiate the proceedings and design its legal framework. In some instances it may result in derailing the case or leading it to the wrong track. In 2012 the Commission instituted the infringements proceedings against Hungary concerning national scheme requiring the compulsory retirement of judges, prosecutors and notaries on reaching the age of $62 .{ }^{45}$ The case clearly related to independence of the judges and impartiality of the courts that are inherent to the rule of law but the Commission focused on the violation of Directive 2000/78 establishing a general framework for equal treatment in employment and occupation. The contested conduct of the Member State affected fundamental values enshrined in Article 2 TEU and remained within the scope of EU law. It was only Attorney General Kokott who mentioned in her opinion that 'abrupt forcing judges into retirement may give rise to doubts as to the independence, and therefore the quality, of the court' guaranteed in Article 47 of the Charter. ${ }^{46}$ Shortly after the

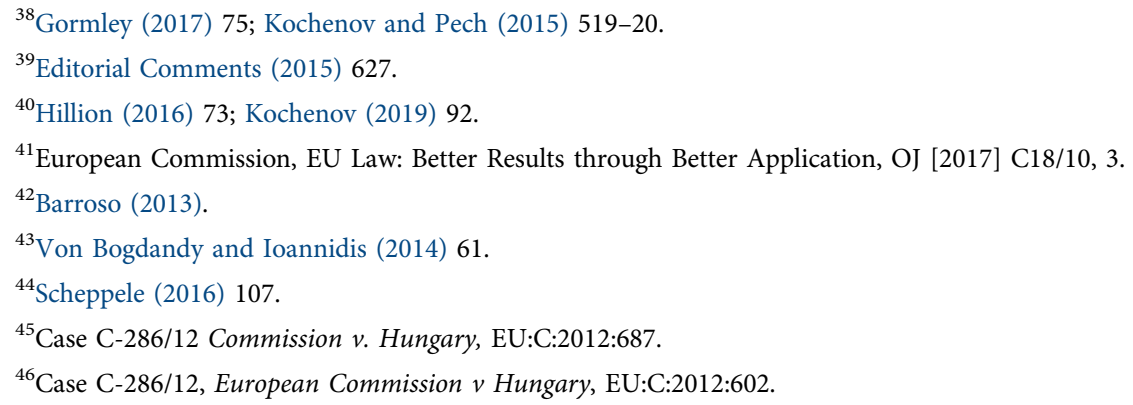


judgement, the government submitted a new bill to pass special rules for those who were unlawfully dismissed, either reinstatement into their former position or general compensation, to comply with the requirements following from the judgement. ${ }^{47}$ Most commentators agree that infringement action against was successful in legal terms and led the Hungarian government to tactically retreat, however, it did not prevent erosion of the rule of law. ${ }^{48}$ Analysing the Polish example, it is worth mentioning two important cases which have initiated a modern approach to the infringement action, paving the way for tackling the violations of fundamental values.

First, the case Comission v. Poland concerning the large-scale logging of trees in the Białowieża Forest, one of the last and largest primeval forests in Europe. ${ }^{49}$ In 2017 the Polish authorities posed a the risk of serious and irreparable damage for the habitats and the integrity of the Natura 2000 site. In this respect, it is not the judgement that is at the centre of the matter but the order for interim measures applied within the framework of infringement proceedings. For the first time in history the CJEU imposed, pursuant to Article 279 TFEU, a periodic penalty payment of at least EUR 100000 per day in the event that that Member State fails to comply with the order. The order for interim measures supported by a financial penalty has proved to be an effective tool discouraging Polish authorities from further illegal operations. Despite the initial declarations, Polish government has also complied with the Court's judgement establishing a breach of environmental directives. What is more important is that the CJEU stated that the purpose of a financial penalty is 'to guarantee the effective application of EU law, such application being an essential component of the rule of law, a value enshrined in Article 2 TEU and on which the European Union is founded'. ${ }^{50}$ Thus 'the effective application of EU law' is another important element of the rule of law in addition to these generally recognised. A violation of acquis that affects an effective application of EU law may adversely impact on a rule of law.

This statement leads to a second important case concerning the Portuguese law on temporary reduction of remuneration paid to court's members, assessed by the CJEU from the perspective of effective judicial protection and independence of the judges. The scope of the review in the context of Article 19(1) TFEU and 47 of the Charter was determined by the national court referring the preliminary question. In Associação Sindical dos Juízes Portugueses the Court held that 'Article 19 TEU, which gives concrete expression to the value of the rule of law stated in Article 2 TEU, entrusts the responsibility for ensuring judicial review in the EU legal order not only to the Court of Justice but also to national courts and tribunals (...) The very existence of effective judicial review designed to ensure compliance with EU law is of the essence of the rule of law'. ${ }^{51}$ In this regard the violation of the law encroaching upon the principle of effective judicial protection of individuals' rights under EU law may affect the rule of law. The Court further explained that Article 19 (1) TEU relates to 'the fields covered by Union law', irrespective of whether the Member States are 'implementing Union law', within the meaning of Article 51(1) of the Charter. ${ }^{52}$ More importantly, the case at issue does not have to

\footnotetext{
${ }^{47}$ Gyulavári and Hós (2013) 295-96.

${ }^{48}$ Scheppele (2016) 110; Kochenov and Pech (2016) 1068.

${ }^{49}$ Case C-441/17 Commission v Republic of Poland.

${ }^{50}$ Case C-441/17 R Commission v Republic of Poland, EU:C:2017:877, 102.

${ }^{51}$ Case C-64/16 Associação Sindical dos Juízes Portugueses, EU:C:2018:117, 32, 36.

${ }^{52}$ Case C-64/16 Associação Sindical dos Juízes Portugueses, EU:C:2018:117, 29.
} 
involve the application or interpretation of EU law as far as the national court may potentially rule on the matter. ${ }^{53}$

Both cases indicate that the Member State may breach the EU acquis while at the same time contravening the rule of law. The breach may fall within the scope of EU law regardless of the requirement prescribed in Article 51 (1) of the Charter, that is applied in respect of violations of the provisions of the Charter. In this regard the procedure defined in Article 258 TFEU may be a valuable instrument to remedy inefficiencies to the values envisaged by Article 2 TEU. There is also possibility of using direct action enshrined in Article 259 TFEU initiated by the Member State against another Member State violating the rule of law. This procedure is not demanding in terms of the legal requirements for its activation but is unlikely to be launched due to the political unwillingness of the EU Member States to act against each other. Both procedures can be launched to remedy a breach of Union values simultaneously with the Rule of Law Framework or mechanism described in Article 7 TEU. However the infringement procedure may not be based solely on the violation of Article 2 TEU.

Although there was some scepticism about the effectiveness of infringement actions in cases of systemic breach of the rule of law, in the case of Poland this proved to be an instant solution. The following two cases concerning the independence of the judiciary are definitely groundbreaking for ensuring respect for the rule of law in the Union legal order. Institution of the proceedings by the Commission in line with interim measures caused the governing majority to withdraw from the most controversial legal changes clearly affecting the values laid down in Article 2 TEU.

In December 2017, in parallel with issuing the 4th Rule of Law Recommendation and reasoned proposal for a Council decision under Article 7(1) TUE, the Commission announced to take the next step in infringement procedure against Poland for breaches of EU law by the Law on the Ordinary Courts Organisation, referring Poland to the CJEU. ${ }^{54}$ In action brought in March 2018, the Commission submitted that, by introducing provisions distinguishing between the retirement age for men and women working as ordinary judges, Supreme Court judges, and prosecutors, and by lowering the retirement age applicable to ordinary court judges, Poland has failed to fulfil its obligations under Article 157 TFEU and of Directive 2006/54. Moreover, by vesting the Minister for Justice with a discretion to prolong the period of active service of individual ordinary court judges, Poland violated the combined provisions of the second subparagraph of Article 19(1) TEU and Article 47 of the Charter ${ }^{55}$ In this case, it is apparent that the Commission combined the lessons learned from the Hungarian and Portuguese experience. The first complaint was based on violation of the equal treatment in employment and occupation, and the other on infringement of effective judicial protection and the independence of the judges being the essential components of the rule of law protected under Article 2 TFEU.

Just one week after Commission initiated infringement proceedings, a group of the Parliament deputies submitted a bill to amend the Law on the organisation of ordinary courts, the Law on the National Council of the Judiciary and the Law on the Supreme Court. The new law set the

\footnotetext{
${ }^{53}$ Case C-64/16 Associação Sindical dos Juízes Portugueses, EU:C:2018:117, 40.

${ }^{54}$ European Commission, Press release, Rule of Law: European Commission acts to defend judicial independence in Poland (2017) <http://europa.eu/rapid/press-release_IP-17-5367_en.pdf> accessed 1 May 2020.

${ }^{55}$ Case C-192/18 Commission v Republic of Poland.
} 
retirement age for judges and prosecutors at 65 years for men and women and empowered the National Council of the Judiciary to decide on the period of prolongation of the active service of a judge of the ordinary courts. ${ }^{56}$ Consequently the Polish government submitted that the infringement action case was devoid of purpose and should have been withdrawn because all of the provisions challenged in these proceedings have been repealed and their effects eliminated. In November 2019 the CJEU delivered a judgement declaring that Poland infringed Article 157 TFEU and Directive 2006/54/EC by instituting a different retirement age for men and women judges of the ordinary courts, the Supreme court, and public prosecutors. Moreover by lowering the retirement age of judges and vesting the Minister for Justice with the discretion to extend the active period of service, Poland violated Article 19(1) second subparagraph, TEU. ${ }^{57}$

The most significant case concerning irremovability of the judges was initiated in October $2018,^{58}$ when the Commission decided to institute an infringement action against Poland in connection with new law on the Supreme Court. ${ }^{59}$ The Commission claimed that the provisions lowering the retirement age of judges, appointed to the Supreme Court before the date of entry into force of that law, infringed the principle of security of tenure of judges. The law immediately affected 27 of the 72 judges and the First President of the Supreme Court, whose six-year term of office was constitutionally guaranteed until April 2020. Furthermore, the Commission argued that granting the President discretion to extend the active mandate of Supreme Court judges, infringed the principle of judicial independence. The Commission refrained from relying on the provisions on age discrimination and based its complaint solely on an infringement of Article 19(1) TFEU in conjunction with Article 47 of the Charter. In October 2018, the CJEU issued interim measures, as requested by the Commission, ordering Poland to restore the Supreme Court to its situation before 3 April 2018, when the contested law entered into force, until the final judgement is rendered in the case. ${ }^{60}$ In order to comply with the obligation, in November 2018 Poland amended the Law on the Supreme Court under which judges were retained or re-instated in office and the President of the Republic was deprived of the right to decide on the extension of a judge's term of office. ${ }^{61}$ However, the new law encouraged judges to remain retired by offering preferential financial conditions for pensions than those generally provided for judges. In June 2019 the CJEU issued a ruling in expedited procedure declaring that by lowering the retirement age of the judges of the Supreme Court and by granting the President of the Republic the discretion to extend the period of judicial activity of Supreme Court judges, Poland violated second subparagraph of Article 19 (1) TEU. ${ }^{62}$

The judgements cited above, enhanced by the elaborated opinions of Advocate General Tanchev, have provided answers to several important questions concerning the protection of values through infringement procedures. The CJEU implicitly confirmed the complementary

\footnotetext{
${ }^{56}$ Act of 12 April 2018 amending the Act - Law on the Common Court System, the Act on the National Council of the Judiciary and the Act on the Supreme Court, OJ. 2018 item 848.

${ }^{57}$ Case C-192/18 Commission v Republic of Poland, EU:C:2019:924.

${ }^{58}$ Case C-619/18 Commission v Republic of Poland.

${ }^{59}$ Act of 8 December 2017 on the Supreme Court, O.J. 2018 item 5.

${ }^{60}$ Case C-619/18 R, Commission v. Republic of Poland, EU:C:2018:1021.

${ }^{61}$ Act of 21 November 2018 amending the Supreme Court Act, O.J. 2018 item 2507.

${ }^{62}$ Case C-619/18 Commission v Republic of Poland, EU:C:2019:531.
} 
relationship between the infringement procedure and the sanctioning mechanism. This issue was directly referred to by the Advocate General, indicating that Article 7 TEU and Article 258 TFEU are autonomous procedures and may be applied in parallel. ${ }^{63}$ The CJEU rejected the arguments of Polish government, that organisation and functioning of national judiciary falls exclusively within the national competence. It follows that, while performing their functions the Member States are still required to comply with their obligations deriving from EU law. ${ }^{64}$ The legal reform introduced by the Polish authorities concerning the lowering of the retirement age for judges has been seen from the perspective of irremovability and independence of the judiciary. It recalls the arguments presented in Associação Sindical dos Juizes Portugueses rather than focusing on the principle of equal treatment in employment and occupation as shown in Commission v. Hungary. However the Court has not clearly explained the relation between Article 19(1) TEU and Article 47 of the Charter, using the latter as the source of inspiration and stating that access to an independent' court or tribunal is an essential element of effective judicial protection. The Advocate General advised against directly invoking Article 47 of the Charter in cases where a Member State does not implement EU law, since that would imply an extension of the Union competence contrary to Article 6(1) TEU and Article 51(2) of the Charter. ${ }^{65}$

In October 2019 the Commission instituted the third infringement action against Poland concerning the new disciplinary regime for judges, alleging infringement of Articles 19(1) and 267 TFEU. ${ }^{66}$ New regulations introduced by governing majority allow judges of common courts to be subject to disciplinary investigations for their judicial decisions. This also includes the right (and in some instances the obligation) of the national court under Article 267 TFEU to submit a request for a preliminary ruling. In view of the Commission, the new disciplinary regime does not guarantee the impartiality of the new Disciplinary Chamber of the Supreme Court (Izba Dyscyplinarna Sądu Najwyższego), which reviews decisions taken in disciplinary proceedings against judges.

In the case A.K. and Others, ${ }^{67}$ the CJEU expressed its doubts whether the Disciplinary Chamber meets the requirements of the independent and impartial court, but left the assessment to the referring court. Shortly after the Supreme Court issued a ruling finding that the Disciplinary Chamber is not a court in the meaning of Article 47 of the Charter and Article 6 of the Convention, as well as in the meaning of national law. The Polish authorities disregarded both judgements, claiming that neither the ruling of the CJEU nor the ruling of the Supreme Court have any legal significance for further functioning of the Disciplinary Chamber and the National Council of the Judiciary. In April 2020 the CJEU ordered the long-awaited interim measures suspending the application of the provisions which constitute the basis for the jurisdiction of the Disciplinary Chamber. Moreover Polish authorities are required to refrain from referring cases pending before the Disciplinary Chamber for consideration by a judicial panel which does not meet the requirements for independence indicated in the judgement A.K. and Others. The interim measures were more than welcome, but there was a difference from those previously

\footnotetext{
${ }^{63}$ Case C-619/18 Commission v Republic of Poland, EU:C:2019:325, 50.

${ }^{64}$ Case C-619/18 Commission v Republic of Poland, EU:C:2019:531, 52.

${ }^{65}$ Case C-192/18 Commission v Republic of Poland, EU:C:2019:529, 99-100.

${ }^{66}$ Case C-791/19 Commission v. Republic of Poland.

${ }^{67}$ Joined Cases C-585/18, C-624/18 and C-625/18 A.K. and Others, EU:C:2019:982.
} 
ordered in Białowieza Forest and Commission v. Poland. In the present case, the Commission and the CJEU demonstrated some reluctance, even though the Polish authorities openly and persistently questioned the authority of the judgements issued in the preliminary ruling procedure and their enforcement by the Supreme Court. The Commission was urged to submit the application by the widely-known open letter from legal scholars and non-governmental organisations and decided to reserve right to require a penalty payment at the further stage of the proceedings. Before adjudicating the case, the CJEU demanded a hearing of the parties and the submission of the view by the Advocate General. The underlying reason was the significant impact that the provisional measures were intended to have on the functioning of the judicial authorities of the State. However, public opinion perceived this as an inefficiency of the European institutions responsible for protecting the rule of law. As time has shown, the interim measures applied by the CJEU have not deterred the Disciplinary Chamber from ruling on the waiver of judges' immunity. Cases involving judges' immunities are conducted under the guise of criminal cases as opposed to the 'disciplinary cases' expressly referred to in the CJEU order. Moreover, the Commission has not decided to submit a request for the imposition of penalty payment against Poland in the event of non-compliance with the order for interim measures.

The Polish example demonstrates that a few separate, but well-targeted infringement actions may discourage the member from pursuing further breaches of law. However, the procedure provided for in Article 258 TFEU has revealed few shortcomings. The cases initiated by the Commission have resulted in the withdrawal of the governing majority from the most obvious violations, but have not effectively improved the respect for the rule of law in Poland. The procedure seems too lengthy to effectively respond to violations. The administrative part of the proceedings takes several months before the Commission and judicial part about two years before the CJEU (only one case was determined under expedited procedure). The application of the infringement procedure is limited, as the illegal conduct must remain within the scope of EU law. The commencement of the proceedings and the construction of the case largely depends on the Commission's discretion. The CJEU is bound by the application defined by the Commission, based on the same pleas and arguments as the reasoned opinion.

Still, compared to other mechanisms, the infringement action is a legal procedure safeguarded by the authority of the CJEU and enforcement of the judgements is guaranteed by the pecuniary sanctions provided for in Article 260(2) TFEU. Declaring that the member has failed to fulfil its obligations amounts to a prohibition on the competent national authorities against applying contested provisions and an obligation to take all appropriate measures to enable Union law to be fully applied. The infringement actions instituted against Poland had advantages in terms of the efficiency in reversing the violation and restoring the judges to their positions as comparing with the protection guaranteed by the European Convention on Human Rights. The European Court of Human Rights (ECHR) leaves to the State the choice of the means to be used in its domestic legal system to give effect to judgement. ${ }^{68}$ The case concerning the premature termination of the President of the Hungarian Supreme Court's mandate was successful as regards establishing the violation of the Convention and granting the compensation, but the applicant was not reinstated in his position. ${ }^{69}$ Nevertheless, a large number of

\footnotetext{
${ }^{68}$ Lambert Abdelgawad (2008) 7.

${ }^{69}$ Case 20261/12 Baka v. Hungary.
} 
Polish prosecutors who were degraded by the arbitrary decisions of the Minister of Justice, as they explained 'were inspired by the Hungarian case', and filed complaints to the ECHR. ${ }^{70}$

\section{PRELIMINARY QUESTIONS - A DEFENCE OF 'LAST RESORT'}

The preliminary ruling procedure has developed into one of the most important measures for enforcing EU law against Member States. While from a rule of law point of view the importance of the procedure provided for in Article 267 TFUE can be broadly viewed as positive, it is clear that is has not been designed for extensive use as an enforcement measure. ${ }^{71}$ A common theme is that the preliminary reference procedure appears insufficient for addressing systemic deficiencies in the rule of law, as being not only 'too case-specific' but also 'ill-suited'. ${ }^{72}$ It enables cooperation of the national courts with the Court of Justice and ensures uniform interpretation and application of the EU law. The judgements are binding in relation to the national court which made the reference, as well as to other national courts outside the specific dispute. By virtue of its purpose, this is the least suitable procedure to be applied in the case of infringement of the rule of law by Member States. However, in view of the government actions, the Polish courts has been extensively using the procedure enshrined in Article 267 TFEU submitting questions concerning the principle of the irremovability and independence of the judges. There have been several preliminary questions form Polish courts, which are evidence of the judicial community's struggle against unconstitutional changes introduced by the Polish authorities.

The series of preliminary questions started in August 2018 when one third of the Supreme Court judges was forced to leave their office. In case regarding the coordination of European social security systems, the Supreme Court referred questions concerning premature compulsory retirement of the judges provided for by the new Law on the Supreme Court, ${ }^{73}$ that was later also subject of the infringements proceedings against Poland in case C-619/18. The questions concerned the principle of the irremovability of judges, which the Supreme Court considered to be infringed as the national law lowered the retirement age of judges against their will and made the continuation of their position dependent on the consent of the President of the Republic. The Supreme Court also invoked the case Commission v. Hungary and submitted that national law infringes the principle of non-discrimination on grounds of age as stipulated in Directive 2000/78. In addition, the referring court has decided to apply interim measures by suspending the application of three provisions of new Law on the Supreme Court.

It is worth noting that the most discussed issue was the suspension of national provisions which, in view of the Supreme Court, infringed the principle of the irremovability of judges. According to established case law, confirmed in Factortame and Unibet, the principle of effective judicial protection requires to grant interim relief until the Court of Justice issues a ruling on whether national provisions are compatible with EU law in order to achieve the full effectiveness

\footnotetext{
${ }^{70}$ Case 53626/16 Bilewicz v. Poland; Case 53632/16 Kowalska and Others v. Poland.

${ }^{71}$ Broberg (2017) 111.

${ }^{72}$ Von Bogdandy and Ioannidis (2014) 61.

${ }^{73}$ Case C-522/18, DŚ v Zakład Ubezpieczeń Społecznych Oddziat w Jaśle.
} 
of the judgement to be given. ${ }^{74}$ However, the Polish government has extensively commented that action undertaken by the referring Court is unlawful and ineffective in Polish legal system and in fact violates the Constitution. Moreover, in view of the Polish authorities, the preliminary question was inadmissible, since judicial independence does not directly relate to the merits of the case pending before the Supreme Court. To that effect, the Polish Vice-Minister of Justice invoked the case Falciola, where the Court of Justice declared the reference concerning the impartiality of the Italian judges inadmissible, since national court doubted only as to the 'possible psychological reactions' of certain Italian judges. ${ }^{75}$ However the preliminary reference submitted by the Supreme Court was different from the case Falciola since it related to a legal position of the Polish judges rather to their 'psychological reactions' to the new Law on the Supreme Court. ${ }^{76}$

In response the Polish authorities have taken measures to prevent the preliminary ruling from being delivered or effectively enforced. Poland's Prosecutor General submitted a request to the Constitutional Tribunal to examine the compliance of Article 267 TFEU with the Polish Constitution, so far as it allows the referral of preliminary questions 'relating to the system, form and organization of the judiciary as well as proceedings before judicial authorities of the EU Member State regarding the organization of the national judiciary. ${ }^{77}$ Moreover, in view of the Prosecutor General, the contested provision allowed the national courts to refer preliminary questions bearing no relevance to the subject matter of the main case. It is difficult to imagine what impact a judgement declaring preliminary procedure unconstitutional would have on legal cooperation with Polish judges and effective judicial protection of individuals. It could be assumed that the expected ruling of the Constitutional Tribunal would allow the Polish authorities to disregard the preliminary rulings issued by the Court of Justice in response to questions referred by the Supreme Court and other Polish courts relating to the independence of the judiciary. Challenging the constitutionality of Article 267 TFEU by the Prosecutor General is a doubtful example of improper use of the Constitutional Tribunal to settle political disputes or legal controversies currently pending in Poland. ${ }^{78}$

The measures taken by the Polish Government have not discourage the Supreme Court and the Supreme Administrative Court from raising further requests for preliminary rulings concerning reforms deteriorating Polish judicial system. The main issue concerned the newlyappointed National Council for the Judiciary (Krajowa Rada Sadownictwa) which, according to the Polish Constitution, shall safeguard the independence of courts and judges. Until 2018, the institution was composed of 25 members, 15 of which were elected by the assemblies of the judges, for four years term of office. In line with the law on the National Council for the Judiciary the mandates of all judges-members were terminated prematurely and the new

\footnotetext{
${ }^{74}$ Case C-213/89 The Queen $v$ Secretary of State for Transport, ex parte: Factortame Ltd and others. EU:C:1990:257; Case C-432/05, Unibet $v$ Justitiekanslern, EU:C:2007:163.

${ }^{75}$ Case C-286/88 Falciola Angelo SpA v. Comune di Pavia, EU:C:1990:33.

${ }^{76}$ Biernat and Kawczyńska (2018a).

${ }^{77}$ Prosecutor General of the Republic of Poland, Application to the Constitutional Tribunal of the Republic of Poland in case ref. no. K 7/18 (2018) <https://ipo.trybunal.gov.pl/ipo/view/sprawa.xhtml?\&pokaz=dokumenty\&sygnatura $=\mathrm{K} \%$ 207/18> accessed on 1 May 2020.

${ }^{78}$ Biernat and Kawczyńska (2018b).
} 
members were chosen by the Parliament, in fact, in a manner which makes them dependent on the political authorities. In response, the judicial associations called on judges to boycott the appointments to the new National Council of the Judiciary. The call was a success: only 18 out of 10,000 Polish judges agreed to stand for appointment to the 15 seats in the new Council. The vast majority of new members are directly or indirectly connected with the Minister of Justice. $^{79}$

In November 2019, the CJEU delivered long awaited judgement in case A.K. and Others in response to preliminary questions concerning the newly established Disciplinary Chamber of the Supreme Court, indirectly referring to the status of the new National Council of the Judiciary. ${ }^{80}$ Attorney General Tanchev recommended to adjudicate that the new Disciplinary Chamber does not meet the requirements of judicial independence and impartiality required under Article 47 of the Charter because the judges have been chosen by the National Council of the Judiciary, the body formed and operating in the manner dependent from legislative and executive authorities. ${ }^{81}$ The CJEU presented more restrained approach leaving for the referring court to determine whether the Disciplinary Chamber is an independent and impartial court, taking into consideration the objective circumstances in which it was formed, its characteristics and the means by which its members have been appointed. In exercising this task, the national court should establish whether the National Council of the Judiciary, as the body taking part in the appointment of the judges, meets the standards arising from EU law and offers sufficient guarantees of independence. The judgement of the CJEU may be criticised as too cautious in comparison with the approach presented by the Attorney General. Leaving the enforcement of a preliminary ruling to a referring court was not recognised by Polish authorities in the same way as would be the case with a definite decision of an international tribunal. It could be argued that the CJEU's restrained approach was motivated by the imminent impact that such a clear statement would have on the functioning of the judicial authorities of the State and the status of more than 600 judges appointed or promoted with the participation of the new National Council of the Judiciary. Moreover, adjudicating the context of a request for a preliminary ruling imposes certain restrictions on the Luxembourg court. The CJEU is not authorised under Article 267 TFEU to apply EU law to a particular case, but to rule on the interpretation of the Treaties and acts adopted by the EU institutions.

Following the preliminary ruling, in December 2019 the Supreme Court adjudicated that the Disciplinary Chamber is not a court in the meaning of Article 47 of the Charter, as well as in the meaning of national law. ${ }^{82}$ The judges considered the main characteristics of the chamber, the extensive autonomy and a special status as an exceptional court, which - according to the Polish constitution - can actually only be formed in wartime. The Supreme Court declared that the judges of the Disciplinary Chamber were elected by the National Council of the Judiciary - an institution dependent from legislative and executive authorities. It follows that each court in Poland, when hearing a case, is obliged to examine on its own initiative whether the standard of independence and impartiality of judicial authorities set out in the CJEU judgement is ensured.

\footnotetext{
${ }^{79}$ Matczak (2018) 8.

${ }^{80}$ Joined cases C-585/18, C-624/18 and C-625/18 A.K. and Others, EU:C:2019:982.

${ }^{81}$ Joined cases C-585/18, C-624/18 and C-625/18 A.K. and Others, EU:C:2019:551.

${ }^{82}$ Supreme Court judgement of 5 December 2020, ref. no. III PO 7/18.
} 
The governing majority immediately replied with the 'Muzzling law" ${ }^{83}$ effectively preventing the judges from examining whether other courts meet the requirements of independence and therefore guarantee effective judicial protection of the individuals. According to the new law, questioning the legitimacy of the judges is a disciplinary offence punishable, potentially, with dismissal. Consequently, makes it impossible for Polish courts to effectively enforce the CJEU' judgement or request further preliminary rulings in matters concerning the independence of the judges. In April 2020 the CJEU ordered interim measures suspending the functioning of the Disciplinary Chamber of the Supreme Court and the Commission instituted the fourth infringement action against Poland with regards to the 'Muzzling law'.

The series of preliminary questions submitted by the Supreme Court encouraged the judges of ordinary and administrative courts in Poland to wider recourse to the procedure provided for in Article 267 TFEU. In 2018 and 2019 the Polish courts submitted 70 references for a preliminary ruling as compared with a total number of 197 requests made since accession in 2004 . The significant number of questions submitted in the last two years concerned the independence of the judiciary, in particular the irremovability of the judges and the disciplinary regime affecting their judicial activity. ${ }^{84}$ One of the main drawbacks is the length of the proceedings only one case was determined pursuant to an expedited procedure. The annual reports of the judicial activity of the Court of Justice indicates that the average duration of proceedings concerning a request for a preliminary ruling was 16 months in 2018 and 15.5 months in 2019. By the time the CJEU delivers its judgement, the judge hearing the case may face an irreversible consequences affecting their professional status. The case of the Supreme Court demonstrates that the application of interim measures in the main proceedings does not receive the acceptance of the Polish authorities, claiming that the courts are thereby infringing the principle of separation of powers.

Furthermore, Article 267 TFEU gives the national courts a very wide discretion in referring matters to the CJEU. As a result, the Polish courts submitted several questions for a preliminary ruling, some of them falling short to meet the formal requirements of their admissibility. For example, district courts in Łódź and Warsaw inquired as to whether the new regime for disciplinary proceedings against judges in Poland meets the requirements of judicial independence under the second subparagraph of Article 19 (1) TEU. ${ }^{85}$ Both questions were declared inadmissible, since the disputes in the main proceedings were not substantively connected to EU law. In procedure prescribed in Article 267 TFEU, the CJEU does not have a jurisdiction to issue advisory opinions on questions of a general or hypothetical nature. Considering that the preliminary ruling procedure is based on close cooperation with the national courts, the CJEU expressed some views obiter dicta. It held, that the Member State is prohibited to introduce

\footnotetext{
${ }^{83}$ Act of 20 December 2019 amending the Act - Law on the Common Court System, the Act on the Supreme Court and certain other acts, O.J. 2020 item 190.

${ }^{84}$ Case C-522/18, DŚ v Zakład Ubezpieczeń Społecznych Oddziat w Jaśle; case C-537/18, Y.V. v. Krajowa Rada Sadownictwa; joined cases C-558/18 and C-563/18 Miasto Lowicz and Others; C-623/18 Prokuratura Rejonowa w Stubicach; C-624/18, C.P.; C-625/18, D.O.; case C-668/18 BP v UNIPARTS; joined cases C-754/18 A.B and Others $v$ Krajowa Rada Sadownictwa; joined cases C-824/18, A.B. and Others v Krajowa Rada Sadownictwa, Case C-487/19, W. Ż.; Case C-508/19, M.F. v J.M.; Case C-55/20 Ministerstwo Sprawiedliwosci v. R.G.; Case C-132/20, Getin Noble Bank.

${ }^{85}$ Joined Cases C-558/18 and C-563/18 Miasto Łowicz, ECLI:EU:C:2019:775.
} 
provisions which expose the national judges to disciplinary proceedings as a result of the fact that they submitted a reference for a preliminary ruling.

The preliminary ruling procedure has proved to be the defence of 'last resort' for the Polish judges fighting for their independence. It was quite an unexpected choice considering the objectives of this procedure and the limitations imposed by Article 267 TFEU. The main purpose of the procedure is to ensure the uniform interpretation and application of the EU law in the various Member States. It is not designed to tackle systemic infringements to the rule of law. Article 267 TFEU precludes the CJEU from ruling on facts and points of national law and on the compatibility of national rules with Union law. The judgement on the interpretation of EU law is declaratory and, as opposed to infringement proceedings, its application is not safeguarded by imminent financial sanctions. Moreover, the Polish authorities challenge the erga omnes effect of the preliminary rulings, claiming it does not apply outside of the specific dispute in respect of which it was delivered.

\section{CONCLUSIONS}

The analysis of democratic crisis in Poland and the responses provided by the European Union demonstrate that there has been a shift from a political to judicial enforcement of values. The remedies that were deemed to be the least suitable to address the systemic deficiencies in the rule of law, proved to be the most effective solution to defend the independence of the Polish judiciary. Unexpectedly, the most efficient institution to ensure the respect for values enshrined in Article 2 TEU in Poland proved to be the CJEU, providing extensive interpretation of Article 19 (1) TEU and Article 47 of the Charter. Nevertheless the values are still much more difficult to enforce than the law. ${ }^{86}$ While the most serious infringements have been reversed, this has not prevented the Polish authorities from further violating the rule of law.

The dialogue within the Rule of Law Framework initiated by the Commission in January 2016, was conducted for almost two years. The recommendations and the opinion issued by the Commission have not affected the Polish authorities in any way. The same applies to five recommendations issued by the Venice Commission, which to date remain unimplemented in Poland. The Commission action in December 2017 to submit a reasoned proposal for a Council decision in accordance with Article 7(1) TUE has raised high expectations. The European Parliament in resolution of 1 March 2018 on the Commission's decision to activate Article 7 (1) TEU as regards the situation in Poland, called on the Council to take swift action to determine of a clear risk of a serious breach of the rule of law by the Polish authorities. ${ }^{87}$ During the first stage of the procedure, the Council held a few hearings where Polish authorities replied to a series of repetitive questions raised by the representatives of the EU Member States. Until now the ministers still have not taken a formal decision on Poland, even if such a decision does not involve the imposition of any sanctions. Given the progressive violation of the rule of law by the Polish authorities, the Council's inaction is difficult to understand.

\footnotetext{
${ }^{86}$ Kochenov (2017) 423.

${ }^{87}$ European Parliament, Resolution of 1 March 2018 on the Commission's decision to activate Article 7(1) TEU as regards the situation in Poland (2018/2541(RSP)).
} 
It can be accepted that the procedure enshrined in Article 258 TFEU was provided for the purpose of combating single infringements of law, but it was able to reverse the most manifest violations concerning the independence and irremovability of judges. The Court of Justice confirmed that Member States are required to comply with their obligations deriving from EU law while organizing the system of justice. The infringements of judicial irremovably fall within the ambit of Article 19 (1) TEU and Article 47 of the Charter, rather than framework for equal treatment in employment and occupation. The second subparagraph of Article 19 (1) TEU has broad material scope and refers to 'the fields covered by Union law' irrespective of whether the Member States are implementing Union law. The interim measures ordered in connection with the case C-619/18, have resulted in reinstatement of the Supreme Court judges to their office. The commencement of infringement proceedings by the Commission in case C-192/18, followed by opinion of the Advocate General Tanchev, resulted in repealing the law on different retirement age for men and women judges of the ordinary courts. Nevertheless, the successful infringement actions have not induced the Polish authorities to discontinue their actions against judiciary.

While the preliminary ruling procedure is considered to be ill-suited for addressing systemic violations in the rule of law, the Polish courts referred several questions concerning the independence of the judiciary. Procedure enshrined in Article 267 TFEU has been used as a weapon for individual judges opposing governmental attacks on their independence. However the judgement issued in preliminary ruling procedure do not constitute such a deterrent for national authorities as judgement delivered in infringement proceedings. The CJEU does not explicitly declare the violation of EU law, leaving the enforcement of the preliminary ruling to the national courts responsible for the effective application of EU law. As a response, the new disciplinary regime was introduced where judges can face sanctions not only for referring the preliminary questions but also for delivering judicial decisions in the execution of the preliminary rulings. In fact, it prevents the judges from implementation of the CJEU's judgements that is contrary to the principle of effective judicial protection and the principle of sincere cooperation.

Time has shown that only measures secured by sanctions or financial penalties could effectively stop the Polish authorities from introducing illiberal reforms. One of the real concerns of the governing majority is the concept of connecting the EU budget with observation of the rule of law that may result in the withdrawal of European funds for infrastructure and agriculture. Some expectations are raised by the adoption by the European Parliament and the Council a regulation on a general regime of conditionality for the protection of the Union budget. ${ }^{88}$ The act provides for financial measures where 'breaches of the principles of the rule of law in a Member State affect or seriously risk affecting the sound financial management of the Union budget or the protection of the financial interests of the Union in a sufficiently direct way'. This is very important in terms of receiving funding from the Recovery and Resilience Facility which aims to address the impact of the COVID-19 crisis on EU economies.

Despite the application of the political and legal mechanisms provided for in the Treaties, the erosion of the rule of law in Poland can still be observed. Existing instruments have proved ineffective in terms of the comprehensive enforcement of EU fundamental values. It is noticeable

\footnotetext{
${ }^{88}$ European Parliament and the Council, Regulation 2020/2092 of 16 December 2020 on a general regime of conditionality for the protection of the Union budget, OJ [2020] L 433I/1.
} 
that the 'new' Commission is more cautious in addressing the violations of the rule of law by the Polish authorities. Additionally, the progressive infringements are not reflected in the procedure pending in the Council under Article 7 TEU. The actions taken by the EU institutions must be more meaningful and targeted precisely at the systemic violations of the rule of law. Each infringement shall be immediately responded to and made visible on an international forum. There should be stronger conditionality between the observance of the rule of law and the implementation of the Unions' budget. Due to the scale and gravity of the infringements affecting the democratic institutions in Poland, the enforcement of fundamental values in the EU cannot be assigned to the CJEU alone.

\section{LITERATURE}

Amnesty International, 'Poland: Free courts, free people, judges standing for their independence' (2019) $<$ https://www.amnesty.org/en/documents/eur37/0418/2019/en> accessed 1 May 2020.

Barroso, J. M., 'State of the Union address 2013' (2013) < https://europa.eu/rapid/press-release_SPEECH13-684_en.htm> accessed 1 May 2020.

Besselink, L., 'The Bite, the Bark and the Howl: Article 7 TEU and the Rule of Law Initiatives', in A. Jakab and D. Kochenov (eds), The Enforcement of EU Law and Values: Ensuring Member State Compliance (Oxford 2017) 128-44.

Biernat, S. and Kawczyńska, M., 'The Role of the Polish Constitution (Pre-2016): Development of a Liberal Democracy in the European and International Context' in Albi, A., and Bardutzky, S. (eds), National Constitutions in European and Global Governance: Democracy, Rights, the Rule of Law (T.M.C. Asser Press 2019) 745-93.

Biernat, S. and Kawczyńska, M., Though this be Madness, yet there's Method in't: Pitting the Polish Constitutional Tribunal against the Luxembourg Court, (2018a) Verfassungblog <https:// verfassungsblog.de/though-this-be-madness-yet-theres-method-int-the-application-of-the-prosecutorgeneral-to-the-polish-constitutional-tribunal-to-declare-the-preliminary-ruling-procedureunconstitut> accessed 1 May 2020.

Biernat, S. and Kawczyńska, M., Why the Polish Supreme Court's Reference on Judicial Independence to the CJEU is Admissible after all, (2018b) Verfassungblog, <https://verfassungsblog.de/why-thepolish-supreme-courts-reference-on-judicial-independence-to-the-cjeu-is-admissible-after-all> accessed 1 May 2020.

Broberg M., 'Preliminary References as a Means for Enforcing EU Law' in Jakab, A. and Kochenov D. (eds), The Enforcement of EU Law and Values: Ensuring Member State Compliance (Oxford 2017) 99111.

Chancellery of the Prime Minister, 'White Paper on the Reform of the Polish Judiciary', (7 March 2018) <https://www.premier.gov.pl/files/files/white_paper_en_full.pdf> accessed 1 May 2020.

Editorial Comments, 'Safeguarding EU values in the Member States - Is something finally happening? (2015) 52 Common Market Law Review 619-28.

European Commission, 'Press release, Rule of Law: European Commission acts to defend judicial independence in Poland', (2017) <http://europa.eu/rapid/press-release_IP-17-5367_en.pdf> accessed 1 May 2020.

Gormley L., 'Infringement Proceedings' in A. Jakab and D. Kochenov (eds), The Enforcement of EU Law and Values: Ensuring Member State Compliance (Oxford 2017) 65-89. 
Gyulavári, T. and Hós, N., 'Retirement of Hungarian judges, age discrimination and judicial independence: a tale of two courts' (2013) 42 Industrial Law Journal 289-97.

Hillion, C., 'Overseeing the Rule of Law in the EU: Legal Mandate and Means', in Closa, C. and Kochenov, D. (eds), Reinforcing the Rule of Law Oversight in the European Union (Cambridge 2016) 59-81.

Kochenov, D. and Pech, L., 'Monitoring and Enforcement of the Rule of Law in the EU: Rhetoric and Reality' (2015) 11 European Constitutional Law Review 512-40.

Kochenov D., 'Article 7' in Kellerbauer, M., Klamert, M. and Tomkin, J. The EU Treaties and the Charter of Fundamental Rights: A Commentary (Oxford 2019) 88-98.

Kochenov, D., 'The EU and the Rule of Law - Naïveté or a Grand Design?' in Maurice, A., Meuwese, A. and Ballin Hirsch, E. (eds), Constitutionalism and the Rule of Law: Bridging Idealism and Realism (Cambridge 2017) 419-45.

Kochenov, D. and Pech, L., 'Better Late than Never? On the European Commission's Rule of Law Framework and its First Activation' (2016) 54 Journal of Common Market Studies 1062-74.

Lambert Abdelgawad, E., The execution of judgments of the European Court of Human Rights, (2nd edn, Council of Europe 2008).

Mangiameli, S., 'Article 2 [The Homogeneity Clause]' in Blanke, H-J. and Mangiameli, S. (eds), The Treaty on European Union (TEU). A Commentary (Springer 2013) 109-55.

Matczak, M., 'Poland: From Paradigm to Pariah? Facts and Interpretations of Polish Constitutional Crisis' (2018) <https://www.researchgate.net/publication/323700896_Poland_From_Paradigm_to_Pariah_ Facts_and_interpretations_of_Polish_Constitutional_crisis> accessed 1 May 2020.

Mijatović, D., (Commissioner for Human Rights of the Council of Europe), 'Report following her visit to Poland from 11 to 15 March 2019' (2019) <https://www.ecoi.net/en/file/local/2012799/CommDH\% 282019\%2917+-+Report+on+Poland_EN.docx.pdf > accessed 1 May 2020.

Österdahl, I., 'Article 7 TEU and the rule of law mechanism: A dissuasive weapon or a paper tiger?' in W. Heusel and J-P. Rageade (eds), The Authority of EU Law. Do We Still Believe in It? (Springer 2019) 241-60.

Pech, L., 'Commission Opinion of 1 June 2016 regarding the Rule of Law in Poland' (2016) <http:// eulawanalysis.blogspot.com/2016/08/commission-opinion-of-1-june-2016.html> accessed 1 May 2020.

Pech, L., 'The Rule of Law as a Constitutional Principle of the European Union' (2009) 04/09 Jean Monnet Working Paper 1-79.

Sadurski, W., 'Adding Bite to a Bark: The Story of Article 7, EU Enlargement, and Jörg Haider' (2010) 16 Columbia Journal of European Law 385-423.

Sadurski, W., 'How Democracy Dies (in Poland): A Case Study of Anti-Constitutional Populist Backsliding' (2018) 18/01 Sydney Law School, Legal Studies Research Paper 1-71.

Sadurski, W., Poland's Constitutional Breakdown (Oxford 2019).

Sargentini, J. and Dimitrovs, A., 'The European Parliament's Role: Towards New Copenhagen Criteria for Existing Member States?' (2016) 54 JCMS: Journal of Common Market Studies, 1085-92.

Scheppele, K. L., 'Enforcing the Basic Principles of EU Law through Systemic Infringement Actions' in Closa, C. and Kochenov, D. (eds), Reinforcing the Rule of Law Oversight in the European Union (Cambridge 2016) 105-32.

Tóth, G. A., 'The Authoritarian's New Clothes: Tendencies Away from Constitutional Democracy', (2017) The Foundation for Law Justice and Society. Policy Brief <http://www.fljs.org/content/authoritariansnewclothes-tendencies-away-constitutional-democracy> accessed 1 May 2020.

UN Human Rights Committee, 'Concluding observations on the seventh periodic report of Poland', (2016) <https://www.ecoi.net/en/file/local/1019364/1930_1481718762_g1626078.pdf> accessed 1 May 2020. 
Venice Commission, 'Opinions for 'Poland' <https://www.venice.coe.int/webforms/documents/? country $=23$ \&year $=$ all $>$ accessed 1 May 2020.

Von Bogdandy, A. and Ioannidis, M., 'Systemic Deficiency in the Rule of Law: What it Is, What Has Been Done, What Can Be Done' (2014) 51 Common Market Law Review 59-96.

Wilms, G., Protecting Fundamental Values in the European Union through the Rule of Law (RSCAS Books 2017).

\section{LEGAL MATERIAL}

Act of 8 December 2017 on the Supreme Court, O.J. 2018 item 5.

Act of 12 April 2018 amending the Act - Law on the Common Court System, the Act on the National

Council of the Judiciary and the Act on the Supreme Court, OJ. 2018 item 848.

Act of 20 December 2019 amending the Act - Law on the Common Court System, the Act on the Supreme

Court and certain other acts, O.J. 2020 item 190.

Act of 21 November 2018 amending the Supreme Court Act, O.J. 2018 item 2507.

Case C-55/20 Ministerstwo Sprawiedliwosci v. R.G.

Case C-64/16 Associação Sindical dos Juizes Portugueses, EU:C:2018:117.

Case C-132/20, Getin Noble Bank.

Case C-192/18 Commission v Republic of Poland.

Case C-192/18 Commission v Republic of Poland, EU:C:2019:529.

Case C-213/89 The Queen v Secretary of State for Transport, ex parte: Factortame Ltd and others. EU:C: 1990:257.

Case C-286/12 Commission v. Hungary, EU:C:2012:687.

Case C-286/12, European Commission v Hungary, EU:C:2012:602.

Case C-286/88 Falciola Angelo SpA v. Comune di Pavia, EU:C:1990:33.

Case 294/83 Parti écologiste 'Les Verts' v European Parliament, EU:C:1986:166.

Case C-432/05, Unibet v Justitiekanslern, EU:C:2007:163.

Case C-441/17 Commission v Republic of Poland.

Case C-441/17 R Commission v Republic of Poland, EU:C:2017:877.

Case C-487/19, W.Z.

Case C-508/19, M.F. v J.M.

Case C-522/18 DŚ v Zakład Ubezpieczeń Spotecznych Oddziat w Jaśle.

Case C-537/18 Y.V. v. Krajowa Rada Sadownictwa.

Case C-619/18 Commission v Republic of Poland.

Case C-619/18 R, Commission v. Republic of Poland, EU:C:2018:1021.

Case C-619/18 Commission v Republic of Poland, EU:C:2019:325.

Case C-619/18 Commission v Republic of Poland, EU:C:2019:531.

Case C-623/18 Prokuratura Rejonowa w Stubicach.

Case C-624/18, C.P.

Case C-625/18, D.O.

Case C-668/18 BP v UNIPARTS.

Case C-791/19 Commission v. Republic of Poland.

Case 53626/16 Bilewicz v. Poland. 
Case 53632/16 Kowalska and Others v. Poland.

Constitutional Tribunal judgement of 17 July 2018, ref. no K 9/17.

Constitutional Tribunal judgement of 26 June 2019, ref. no K 8/17.

Constitutional Tribunal judgement of 24 October 2017, ref. no K 3/17.

Constitutional Tribunal judgement of 20 June 2017, ref no. K 5/17.

Constitutional Tribunal judgement of 11 September 2017, ref. no K 10/17.

Constitutional Tribunal judgement of 26 June 2019, ref. no K 16/17.

Constitutional Tribunal judgement of 20 April 2020, ref. no U 2/20.

Council of the European Union, 'Opinion of the Legal Service. Subject: Commission's Communication on a new EU Framework to strengthen the Rule of Law', (27 May 2014) <https://data.consilium.europa.eu/ doc/document/ST-10296-2014-INIT/en/pdf> accessed 1 May 2020.

European Commission, Communication of the European Parliament, the European Council and the Council Further strengthening the Rule of Law within the Union. State of play and possible next steps, $\operatorname{COM}(2019) 163$ final.

European Commission, 'Communication From The Commission to the Council and the European Parliament on Article 7 of the Treaty on European Union. Respect for and promotion of the values on which the Union is based. $\operatorname{COM}(2003) 606$ final' (2003) <https://eur-lex.europa.eu/legal-content/EN/ TXT/PDF/?uri=CELEX:52003DC0606\&from $=$ EN $>$ accessed 1 May 2020.

European Commission, 'Communication to the European Parliament and the Council. A new EU Framework to strengthen the Rule of Law, $\operatorname{COM}(2014) 158$ final'. (2014) <https://eur-lex.europa.eu/ legal-content/EN/TXT/PDF/?uri=CELEX:52014DC0158\&from =NL> accessed 1 May 2020.

European Commission, EU Law: Better Results through Better Application, OJ [2017] C18/10, 3.

European Commission for Democracy through Law (Venice Commission), 'Report on the rule of law, adopted by the Venice Commission at its 86th plenary session' (Venice, 25-26 March 2011) <https://www.venice. coe.int/webforms/documents/default.aspx?pdffile=CDL-AD(2011)003rev-e> accessed 1 May 2020.

European Commission, Proposal for a Council decision on the determination of a clear risk of a serious breach by the Republic of Poland of the rule of law (COM(2017) 835.

European Commission, Proposal for a Regulation of the European Parliament and of the Council on the protection of the Union's budget in case of generalised deficiencies as regards the rule of law in the Member States, $\operatorname{COM}(2018) 324$ final.

European Commission, 'Recommendation 2016/1374 of 27 July 2016 regarding the rule of law in Poland, OJ [2016] L 217/53', (2016) <https://eur-lex.europa.eu/legal-content/EN/TXT/?uri=uriserv\%3AOJ.L_. 2016.217.01.0053.01.ENG\&toc=OJ\%3AL\%3A2016\%3A217\%3ATOC> accessed 1 May 2020.

European Commission, Recommendation (EU) 2017/146 of 21 December 2016 regarding the rule of law in Poland complementary to Recommendation (EU) 2016/1374, OJ [2017] L22/65 (2016).

European Commission, Recommendation (EU) 2017/1520 Of 26 July 2017 regarding the rule of law in Poland complementary to recommendations (EU) 2016/1374 and (EU) 2017/146, OJ [2018] L228/19.

European Commission, Recommendation (EU) 2018/103 of 20 December 2017 regarding the rule of law in Poland complementary to recommendations (EU) 2016/1374, (EU) 2017/146 and (EU) 2017/1520, OJ [2018] L17/50.

European Parliament, Resolution of 1 March 2018 on the Commission's decision to activate Article 7(1) TEU as regards the situation in Poland (2018/2541(RSP)).

European Parliament resolution of 16 January 2020 on ongoing hearings under Article 7(1) of the TEU regarding Poland and Hungary (2020/2513(RSP)). 
European Parliament and the Council, Regulation 2020/2092 of 16 December 2020 on a general regime of conditionality for the protection of the Union budget, OJ [2020] L 433I/1.

Joined cases C-558/18 and C-563/18 Miasto Lowicz and Others.

Joined Cases C-558/18 and C-563/18 Miasto Łowicz, ECLI:EU:C:2019:775.

Joined Cases C-585/18, C-624/18 and C-625/18 A.K. and Others, EU:C:2019:982.

Joined cases C-585/18, C-624/18 and C-625/18 A.K. and Others, EU:C:2019:551.

Joined cases C-754/18 A.B and Others $v$ Krajowa Rada Sadownictwa.

Case T-337/03, Luis Bertelli Galvez v Commission, ECLI:EU:T:2004:106.

Opinion 2/13, ECLI:EU:C:2014:2454.

Order of the Court of 2 April 2004, Case T-337/03.

Prosecutor General of the Republic of Poland, Application to the Constitutional Tribunal of the Republic of Poland in case ref. no. K 7/18 (2018) <https://ipo.trybunal.gov.pl/ipo/view/sprawa.xhtml? \&pokaz $=$ dokumenty\&sygnatura $=K \% 207 / 18>$ accessed on 1 May 2020. Supreme Court judgement of 5 December 2020, ref. no. III PO 7/18. 